1 Carbonate grain-size distribution in hemipelagic sediments from a laser

\title{
particle sizer
}

\author{
Trentesaux, A., Recourt, P., Bout-Roumazeilles, V., Tribovillard, N.
}

Laboratoire de Sédimentologie et de Géodynamique, UMR 8577, Université des Sciences et Technologies de Lille, SN5, F-59655 Villeneuve d'Ascq Cedex, France e-mail : alain.trentesaux@univ-lille1.fr

\section{Abstract}

Laser grain-sizer instruments provide the opportunity to study the grain size distribution of sediments across a wide size range in a short time. Automatic Tapez une équation ici.measurements can therefore be made, on a routine basis, for a great number of samples. Oceanic studies have proved the utility of these methods in characterizing both climatic changes and changes in sediment provenances. In addition, carbonate content is estimated either directly by $\mathrm{CaCO}_{3}$ measurement, by visual observations, or by proxies such as sediment color reflectance. Nevertheless, the grain size distribution of the carbonate fraction is still a matter of speculation, and only optical observations can distinguish the nature of each carbonate fraction. Here we present the improvements on a method to study rapidly, with a high resolution, the grain size distribution of the carbonate fraction by use of a laser grain-sizer. We describe the basic methodology and apply it to an example from the Pleistocene of the Northern Atlantic Ocean.

\section{Introduction}

In paleoceanographic studies, grain size distribution and carbonate content are often examined. The first parameter is derived by a number of methods, each having some advantages and drawbacks. It provides valuable information on the depositional mechanisms (Clemens and Prell 1990; Rea and Hovan 1995; Prins 1997; Kaiho 1999; Wang et al. 1999) and sea-floor currents (Pudsey 1992; Faugères and Stow 1993; McCave et al. 1995a; McCave et al. 1995b; Diekmann and Kuhn 1997; Michels 2000). Carbonate content is usually obtained by chemical digestion, X-ray diffraction, and, more recently, the use of sediment color reflectance as a proxy for carbonate content (Blum 1997; Balsam et al. 1999). 
In this paper, we discuss a method that facilitates rapid measurement of the two parameters with a good degree of accuracy, including the grain size distribution of the carbonate fraction. The method uses a wide-range laser diffraction size analyzer. A brief application is presented on samples from a Pleistocene climatic transition in Northern Atlantic sediments from an Ocean Drilling Program core. This method offers a good alternative to some classical measurements performed through smearslide observations or differential chemical digestions and microscopic observations (Diekmann and Kuhn 1997).

\section{Method}

\section{Measurement Principle}

For this study, grain size parameters were determined using a Malvern Mastersizer X apparatus. Other manufacturers exist, and in all cases the instruments use the diffraction of a laser light in a cell filled with the sample in suspension in a dispersant (usually deionized water). The diffraction angle is inversely proportional to the grain size and is measured with a photoelectric cell. A series of algorithms are then used to calculate a grain size distribution curve assuming a spherical shape of the particles. For these instruments, manufacturers indicate that typical accuracy is less than $2 \%$ for grain sizes between 900 and $5 \mu \mathrm{m}$ and decreases to about $6 \%$ for finer grain sizes. Manufacturers' reported precision is $2 \%$. The measurement principle is well explained in McCave et al. (1986) and Agrawal et al. (1991).

The relative advantages or drawbacks of this technique and other grain-size analyzers have been well documented (McCave and Syvitski 1991; Loizeau et al. 1994; Kench and McLean 1997; Konert and Vandenberghe 1997; Beuselinck et al. 1998). Among the advantages that led us to choose this technique instead of others is the good precision and the rapidity of the measurement, allowing the study of large sample sets. Four lenses are available, depending on the estimated grain size distribution: 45, 100, 300, and $1000 \mathrm{~mm}$, respectively for $0.180,0.5180,1.2600$, and $4.02000 \mu \mathrm{m}$, respectively. The $100 \mathrm{~mm}$ lens was selected because it was the most suitable for our tests.

\section{Sample Preparation}

In the case of a coarse fraction, the sediment can be gently sieved under deionized water. Samples were first put in suspension in deionized water and then gently shaken for two hours to achieve disaggregation. For organic-rich sediments, it might be interesting to use $\mathrm{H} 2 \mathrm{O} 2$ to oxidize organic matter and to break up the floccules; this has not been tested in our 
used to complete the sediment dispersion. Measurements showed that after more than two hours of gentle shaking, the suspended sediment is well disaggregated. Moreover, the use of ultrasonic dispersion has a dramatic effect on some particles containing trapped water inclusions, such as foraminifers or vesicular volcanic glass. Repeated measurements after increasing periods of ultrasonic dispersion clearly demonstrate the disintegration of the foraminifer tests and vesicular glass particles, leading to a decrease in the mean sediment grain size. Broken foraminifer tests can subsequently be observed in residues on smear slides.

The suspension is then gently poured into the fluid module of the granulometer, filled with tap water. Tap water was chosen rather than degassed water for reasons of simplicity. The background noise introduced by the degassing water (Loizeau et al. 1994) is nevertheless small and is included in the measured background that is later subtracted from the total measurement. Ultrasonics is used before pouring the sediment in order to decrease the degassing time. The final suspension has a concentration varying from 10 "4 to $0.1 \%$ (expressed as a relative volume concentration). Measurement begins after two minutes of continuous stirring to allow most of the air bubbles created by the sediment introduction to escape.

\section{Measurement and Calculations}

Grain-size distribution is calculated using the refractive index of quartz (1.56) for the sediment and 1.0 for the water. After measurement, the data are saved in a file containing all percentiles and a variety of calculated parameters. Each size class $I$ is characterized by an amount noted $T(i)$. The computer software also computes a cumulative and frequency histogram for each sample. The data are transferred to a spreadsheet using a macro that samples the data at increments chosen by the user (in our case, \#/6). \# (phi) is the negative logarithm to the base 2 of the particle diameter in millimetres.

\section{Distribution of the Carbonate Fraction.}

The major advantage of a laser diffraction grain-size analyzer is the ability to measure a sediment suspended in water. This allows the addition of the necessary amount of hydrochloric acid $(\mathrm{HCl})$ to dissolve the calcium carbonate contained in the sediment, an approach already used by McCave et al. (1986) to characterize the non carbonate fraction. $\mathrm{HCl}$ is added in excess to the suspension, verified by stabilization of the measured $\mathrm{pH}$ at a value of 1 for more than one minute. The instrument does not suffer from the acid conditions, because the main parts are made of Teflon, glass, or stainless steel. A repeat measurement is 
101 performed after acid digestion to obtain a "non carbonate fraction" grain-size distribution.

102 For each size class $i$, the decarbonated fraction is expressed as $D(i)$.

After transferring data to the spreadsheet, the carbonate fraction $C(i)$ is calculated by

104 the formula

$$
C(i)=T(i)-D(i) \times\left(1-\mathrm{CaCO}_{3}\right)
$$

106 derived from McCave et al. (1995b), where $C(i)$ is the calcium carbonate fraction of the size

107 class $i, T(i)$ is the total sediment fraction of size class $i, D(i)$ is the decarbonated sediment

108 fraction of size class $i$, and $\mathrm{CaCO}_{3}$ is the calcium carbonate content in the sediment, as described next.

Calculation of the $\mathrm{CaCO}_{3}$ Percentage.

Although it is possible to measure the $\mathrm{CaCO}_{3}$ content by classical chemical

113 techniques, we found that the Malvern Mastersizer was able to calculate automatically the

114 carbonate content of a sediment measured first as a total sediment and then as a decarbonated

115 sediment. Among the different parameters measured by the instrument, "obscuration"

116 corresponds to the loss of transmitted light intensity due to the presence of particles in

117 suspension. For a monodispersed sample, obscuration is a direct function of grain size,

118 concentration, and path length (width of the measurement cell) according to the following

119 formula

$$
V=\frac{-d \times \ln (L-O)}{3.1}
$$

121 (Malvern Instruments Ltd. Reference manual), where $V$ is the volume concentration as 122 relative percentage, $d$ is the particle diameter in microns, $L$ is the path length illuminated expressed in millimeters, and $O$ is the obscuration.

124 It follows from this relationship that the decrease in concentration between the two 125 grain size measurements (before and after acid digestion) will cause a decrease in the 126 obscuration directly related to the loss of particles dissolved by hydrochloric acid.

The $\mathrm{CaCO}_{3}$ content can therefore be directly expressed by the formula

$$
\mathrm{CaCO}_{3}=\frac{O b s T-O b s D}{O b s T}
$$

129 where $\mathrm{CaCO}_{3}$ is $\mathrm{CaCO}_{3}$ the calcite content, ObsT is the obscuration measured when the total sample is in suspension, and ObsD is the obscuration measured after acid digestion

131 (decarbonated sample). 
This was tested by measuring the carbonate content both by chemical digestion and by 133 obscuration difference using Equation 3 (Fig. 1). Although the correlation is very good 134 (correlation coefficient $r=0.9877$ ), it is notable that the correlation line is not $1: 1$, indicating 135 that the carbonate content measured with the obscuration difference has to be calibrated to 136 better represent the carbonate content. This is most likely because obscuration also depends 137 on the grain size (Malvern Instruments Ltd., Reference Manual). We therefore suggest that a 138 calibration should be made with samples from each new location. Substitution of Equation 3 into Equation 1 gives

$$
C(i)=T(i)-D(i) \times \frac{O b s D}{O b s T}
$$

141 Equation 4 facilitates drawing of the cumulative or frequency distribution curve of the carbonate fraction from the sediment, permitting identification of the mode, mean, sorting index, or skewness. Figure 2 illustrates the three curves for a sample from the Northern Atlantic Ocean.

\section{Application to pelagic sediments}

To test the method on natural samples, we selected 16 samples from the ODP leg 162, site 980, in the Northern Atlantic Ocean, on the western slope of the Rockall Trough at a depth of $2180 \mathrm{~m}$ (Jansen et al. 1996). To both emphasize the possible changes in the carbonate fraction of the sediment and to scan a wide variety of $\mathrm{CaCO}_{3}$ content, we used samples dated at the transition between the Pleistocene isotope stages 6 and 5e, between 25.26 and $20.56 \mathrm{~m}$ below sea floor (146.5 to $119.0 \mathrm{ka}$, respectively). The sediment consists of calcareous oozes and muds. It is rich in foraminifers of diameter greater than the measurement range. For that reason, it was decided to sieve the sediment at $80 \mu \mathrm{m}$ very gently under deionized water to remove the large foraminifer fraction. The 16 samples were then prepared as described, and their grain-size distribution was measured on both total and decarbonated fraction.

A number of analyses have been performed onboard and in the shore-based

160 size measured on the bulk sediment range between 6.5 and $20 \mu \mathrm{m}$ with no trend in the depth 161 distribution (Fig. 3A). After acid digestion (decarbonated sample in Fig. 3A), the usually higher values of the mean grain size indicate that the terrigenous fraction is slightly coarser than the carbonate fraction that is probably rich in nannofossils. The carbonate-fraction mean 
164 grain size varies between 4.5 and $16.5 \mu \mathrm{m}$, with variations similar to those observed in the other fractions. It is clear from Fig. 3A that the grain-size distribution of the bulk sediment in this example is not an informative parameter, even if it is sometimes interesting to illustrate variations in the sediment regime related to climatic change (Wang et al. 1999). The age model has been established from the $\delta^{18} \mathrm{O}$ stratigraphy measured on Cibicides sp. (Fig. 3B, Jerry McManus, unpublished data). The isotope stage 6-5e transition is especially well pronounced at this location because of its proximity to the polar front in glacial stages but distance from it during interglacial stages. Using the technique described above, $\mathrm{CaCO}_{3}$ content ranges from 11.5 to $84 \%$ (Fig. 3C). There is a clear increase in carbonate at the transition, interpreted to be related to an increase in carbonate productivity during isotope stage 5e (considering no change in the dissolution conditions (Milliman and Droxler 1996) or winnowing removal of the carbonate (Michels 2000)) with a time lag that can be evaluated as 0.3 to $0.4 \mathrm{ka}$ between the change in $\delta^{18} \mathrm{O}$ composition and the change in $\mathrm{CaCO}_{3}$. The duration of this interval might be explained, in part, by the sampling interval. Reflectance measured onboard (Fig. 3D, Ortiz et al. 1999), on the contrary, is directly related to C content as observed in numerous oceanic locations (e.g., Blum 1997).

The $\mathrm{CaCO}_{3}$ content estimated from the obscuration difference (Equation 3) is used to produce the 16 carbonate grain-size distributions (Fig. 4). The surface of the histograms is directly related to the general carbonate content and emphasizes the climatic transition around $130 \mathrm{ka}$. The carbonate-fraction distribution indicates two modal sizes centred at 2 and $32 \mu \mathrm{m}$. Smear-slide observations indicate that these modes correspond to nannofossils and planktonic foraminifers, respectively. During the end of glacial stage 6 , there is a clear dominance of nannofossils over foraminifers in most samples. This is not the case during the early part of stage 5e (samples at 130.5 and $126.5 \mathrm{ka}$ ) when the foraminifer modal class is of the same order of magnitude as that of the nannofossil, indicating that foraminifers are a major contributor (in volume or in weight) to the $\mathrm{CaCO}_{3}$ sedimentation. After this transition, nannofossil abundance increases rapidly to assume the main mode while the foraminifer mode increases slowly. The reasons for this two-phase transition between the glacial and an interglacial stage are not discussed here but indicate a phase lag that has to be confirmed by studies on other transitions or over a longer time period.

\section{Discussion}

The technique described has great potential utility, making possible a fast determination of the carbonate content with a good accuracy and yielding the carbonate 
distribution over the studied grain size range. Nevertheless, there is always a vital need to verify the interpretations by visual observations, especially due to some uncertainties, such as sample quality and instrumental limitations.

Sample Quality

203 Detrital Calcite.-Calcite can be present in oceanic sediments as a contributor to the detrital 204 fraction. Although calcite is easily distinguished on smear slides, the method we describe 205 cannot differentiate between biogenic and detrital calcite. For that reason, we recommend 206 closer examination of some samples to avoid misinterpretations. At site 980 in the Northern Atlantic Ocean, smear-slide observations indicate the absence of such a contribution along the study interval.

209 Diagenetic Calcite.-Grain size analyses can easily be performed on non cemented samples.

210 The technique described here must be applied to sediments that have not suffered from any 211 carbonate diagenesis. None of the present-day existing methods for measuring grain size can make the distinction between diagenetic calcite and biogenic calcite.

\section{Instrument Limitations}

215 High Carbonate Content.- The accuracy of the $\mathrm{CaCO}_{3}$ content measurement decreases with 216 increasing carbonate concentration, as indicated by the increased scatter in Figure 1 for values 217 greater than $60 \%$. Equation 3 indicates that carbonate content is directly related to the 218 obscuration parameter. The obscuration values have to fall within the grain-sizer range. The 219 instrument can measure with obscurations that are higher or lower $(>30 \%$ or $<10 \%$, respectively; Malvern instrument Ltd. reference manual) than the optimal case, but there is an associated loss of accuracy.

Using these values of obscuration, the maximum carbonate content can be calculated by substituting obscuration values in Equation 3

$$
\mathrm{CaCO}_{3 \mathrm{Max}}=\frac{O b s T_{\max }-P b s D_{\operatorname{Min}}}{O b s T_{\operatorname{Max}}} \times 100=\frac{30-10}{30} \times 100=66.6 \%
$$

If a deterioration of the measurement is acceptable (replacing $\mathrm{Obs}_{\mathrm{TMax}}$ and $\mathrm{Obs}_{\mathrm{DMin}}$ by 50 and 5, respectively; Malvern instrument Ltd. reference manual), then a maximum value of $90 \%$ of carbonate content is obtained using Equation 3. This means that above $66.6 \%$ of carbonate, the carbonate content accuracy decreases rapidly to be non-measurable above 90 
$\%$. ObsT is fixed by the instrument user. It is therefore recommended to introduce a large

232 quantity of bulk sediment when a high carbonate content is expected, to maintain enough 233 material after acid digestion.

234 Low Carbonate Content.-When the carbonate content is too low (approaching 15\%), the measurements approach the accuracy limit of the instrument. Note in Figure 1 that the intercept at the origin is not zero, indicating that in the case of very low carbonate concentration a higher volume is calculated. It also indicates that incorporating acid in the sampling cell could affect the grain-size distribution even if no carbonate is present in the sediment.

Measurement Accuracy of Carbonate Content.-The two previous sections indicate that in some cases, measurement of carbonate content can suffer from a decrease in analysis accuracy if carbonate content is calculated using obscuration parameters. To avoid this problem, it is more suitable to use data on carbonate content from other methods as acid digestion and use Equation 1. However, this causes extra laboratory work and is slower. Furthermore, some problems can occur because the $\mathrm{CaCO}_{3}$ analysis is not performed on strictly the same sample, leading to a loss of precision in calculating the size distribution of the carbonate fraction.

\section{Conclusions}

With the ability to measure the concentration and grain size distribution first on total sediment and then on the same, but decarbonated, sample by the laser diffraction size analyzer, we demonstrate that by using simple mathematical formulae and a spreadsheet program it is possible to calculate the carbonate content and the grain size distribution of the carbonate fraction. A first application on samples from the Stage 5e-6 Pleistocene climatic transition in the Northern Atlantic Ocean with variable carbonate content indicates the reliability of the method. Thus, use of a laser diffraction size analyzer can be of great value in paleoceanographic studies. This rapid method must still take into account the sample quality,

\section{Acknowledgments}

The authors express their thanks to Stéphane Decottignies and Sébastien Lapierre, who worked on the subject in its early stages during student practical works. Michel Dubois reviewed their internal reports and made valuable comments on the methodology. 
We wish to warmly thank Dr Matt Higginson (University of Massachusetts at

265 Dartmouth) for the helpful comments and improvement of an early version of the manuscript.

266 We also express sincere thanks for the constructive reviews of the two reviewers as well as 267 for the helpful comments from associate editor Mitchell Malone.

\section{REFERENCES}

AGRAWAL, Y.C., MCCAVE, I.N., AND RILEY, J.B., 1991, Laser diffraction size analysis, in Syvitski, J.P.M., ed., Principles, Methods, and Application of Particle Size Analysis: Cambridge, U.K., Cambridge University Press, p. 119-128.

BALSAM, W.L., DEATON, B.C., AND DAMUTH, J.E., 1999, Evaluating optical lightness as a proxy for carbonate content in marine sediment cores: Marine Geology, v. 161, p. 141153.

276 BEUSELINCK, L., GOVERS, G., POESEN, J., DEGRAER, G., AND FROYEN, L., 1998, 277 Grain size analysis by laser diffractometry: comparison with the sieve pipette method: Catena, 278 v. 32, p. $193-208$.

279 BLUM, P., 1997, Physical properties handbook: guide to the shipboard measurement of physical properties of deep-sea cores by the Ocean Drilling Program. Available from World Technical Notes, v. 26: College Station, Texas, USA. CLEMENS, S.C., AND PRELL, W.L., 1990, Late Pleistocene variability of Arabian Sea summer monsoon winds and continental aridity: eolian records from the lithogenic component of deep-sea sediments: Paleoceanography, v. 5, p. 109-145.

DIEKMANN, B., AND KUHN, G., 1997, Terrigene Partikeltransporte als Abbild spätquartärer Tiefen - und Bodenwasserzirkulation im Südatlantik und angrenzendem Südpolarmeer: Deutsche Geologische Gesellschaft, Zeitschrift, v. 148, p. 405-429.

FAUGE`RES, J.C., AND STOW, D.A.W., 1993, Bottom-current-controlled sedimentation: a synthesis of the contourite problem: Sedimentary Geology, v. 82, p. 287-297.

291 JANSEN, E., RAYMO, M.E., BLUM, P., ET AL., 1996, Proceedings of the Ocean Drilling 292 Program, Initial Reports, 162: College Station, Texas.

293 KAIHO, K., 1999, Evolution in the test size of deep-sea benthic foraminifera during the past

294120 m.y.: Marine Micropaleontology, v. 37, p. 53-65.

295 KENCH, P.S., AND MCLEAN, R.F., 1997, A comparison of settling and sieve techniques 296 for the analysis of bioclastic sediments: Sedimentary Geology, v. 109, p. 111-119. 
KONERT, M., AND VANDENBERGHE, J., 1997, Comparison of laser grain size analysis

298 with pipette and sieve analysis: a solution for the underestimation of the clay fraction:

299 Sedimentology, v. 44, p. 523-535.

300 LOIZEAU, J.-L., ARBOUILLE, D., SANTIAGO, S., AND VERNET, J.-P., 1994, Evaluation

301 of a wide range laser diffraction grain size analyser for use with sediments: Sedimentology, v.

302 41, p. 353-361.

303 MCCAVE, I.N., BRYANT, R.S., COOK, H.F., AND COUGHANOWR, C.A., 1986,

304 Evaluation of a laser diffraction- size analyser for use with natural sediments: Journal of 305 Sedimentary Petrology, v. 56, p. 561-564.

306 MCCAVE, I.N., MANIGHETTI, B., AND BEVERIDGE, N.A.S., 1995a, Circulation in the 307 glacial North Atlantic inferred from grain size measurements: Nature, v. 374, p. 149-152.

308 MCCAVE, I.N., MANIGHETTI, B., AND ROBINSON, S.G., 1995b, Sortable silt and fine 309 sediment size/ composition slicing: Parameters for palaeocurrent speed and 310 palaeoceanography: Palaeoceanography, v. 10, p. 593-610.

311 MCCAVE, I.N., AND SYVITSKI, J.P.M., 1991, Principles and methods of geological 312 particle size analysis, in Syvitski, J.P.M., ed., Principles, Methods, and Application of Particle 313 Size Analysis: Cambridge, U.K., Cambridge University Press, p. 3-21.

314 MICHELS, K.H., 2000, Inferring maximum geostrophic current velocities in the Norwegian315 Greenland sea from settling-velocity measurements of sediment surface samples: methods, 316 application, and results: Journal of Sedimentary Research, v. 70, p. 1036-1050.

317 MILLIMAN, J.D., AND DROXLER, A.W., 1996, Neritic and pelagic carbonate 318 sedimentation in the marine environment: ignorance is not a bliss: Geologische Rundschau, v. 319 85, p. 496-504.

320 ORTIZ, J.D., O'CONNELL, S., AND MIX, A., 1999, Spectral reflectance observations from 321 recovered sediments, in Raymo, M.E., Jansen, E., Blum, P., and Herbert, T.D., eds., 322 Proceedings of the Ocean Drilling Program, Scientific Results, 162: College Station, p. 259323264.

324 PRINS, M.A., 1997, Pelagic, hemipelagic and turbidite deposition in the Arabian Sea during 325 the Late Quaternary: Universiteit Utrecht, Faculteit Aardwetenschappen, Mededelingen, v. $326168,192 \mathrm{p}$.

327 PUDSEY, C.J., 1992, Late Quaternary changes in Antarctic bottom water velocity inferred 328 from sediment grain size in the northern Weddel Sea: Marine Geology, v. 107, p. 9-33. 
329 REA, D.K., AND HOVAN, S.A., 1995, Grain size distribution and depositional processes of 330 the mineral component of abyssal sediments: lessons from the North Pacific: 331 Paleoceanography, v. 12, p. 251-258.

332 WANG, L., SARNTHEIN, M., ERLENKEUZER, H., GRIMALT, J., GROOTES, P., 333 HEILIG, S., IVANOVA, E., LIENAST, M., PELEJERO, C., AND PFLAUMANN, U., 1999, 334 East Asian monsoon climate during the late Pleistocene: High resolution sediment records 335 from the South China Sea: Marine Geology, v. 156, p. 254-284. 


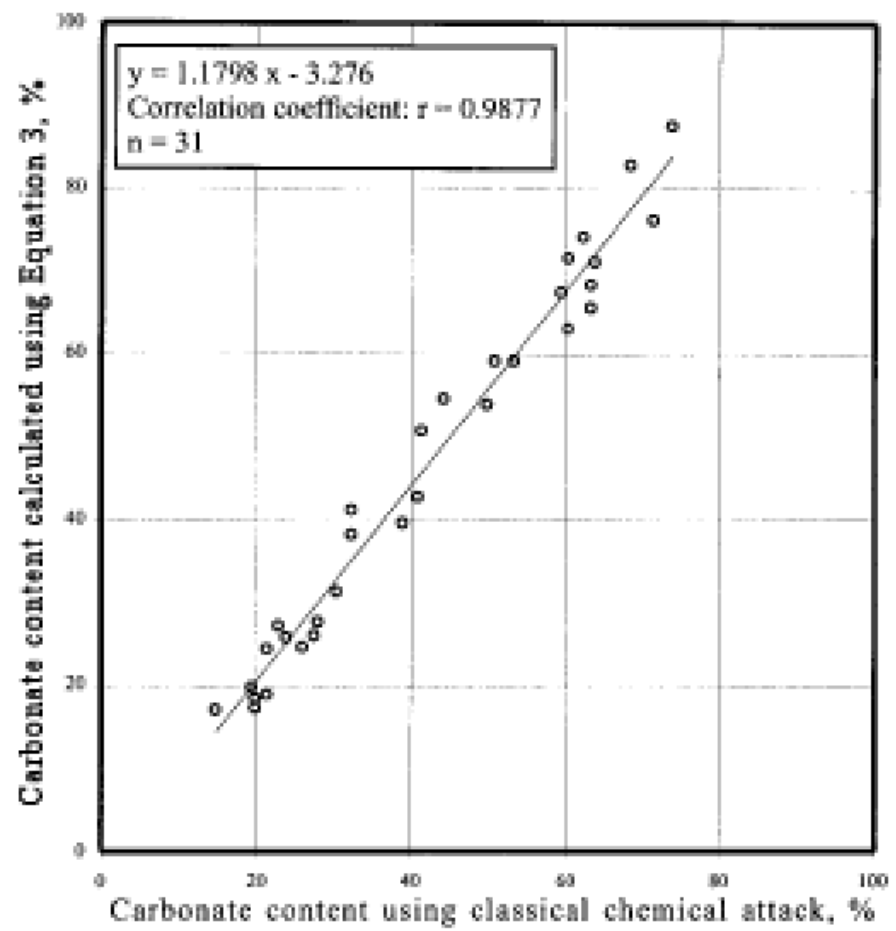

339 Fig. 1. Relationship between carbonate content measured by acid digestion and calculated 340 using obscuration parameters on 31 Pleistocene samples from the Northern Atlantic Ocean 341 (ODP Site 980). Values in \%. 


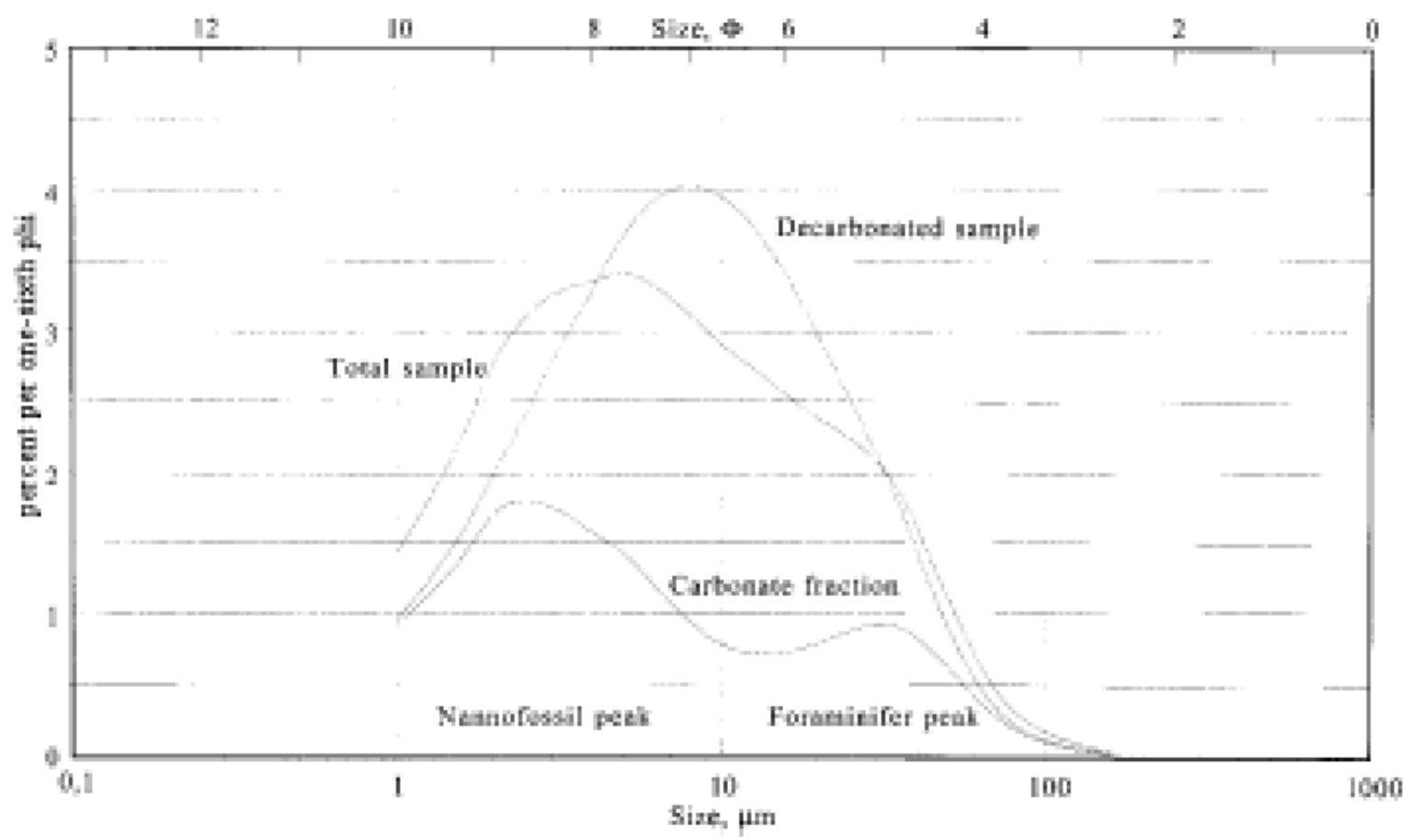

343

344 Fig. Grain-size distribution of the sediment before acid digestion (total sediment size 345 distribution: open squares), after acid digestion (decarbonated sediment size distribution: 346 black circles) and calculated carbonate size distribution (carbonate fraction size distribution: 347 black triangles). Sample: 980-C-3H03 016-018, $124.5 \mathrm{ka}$. 

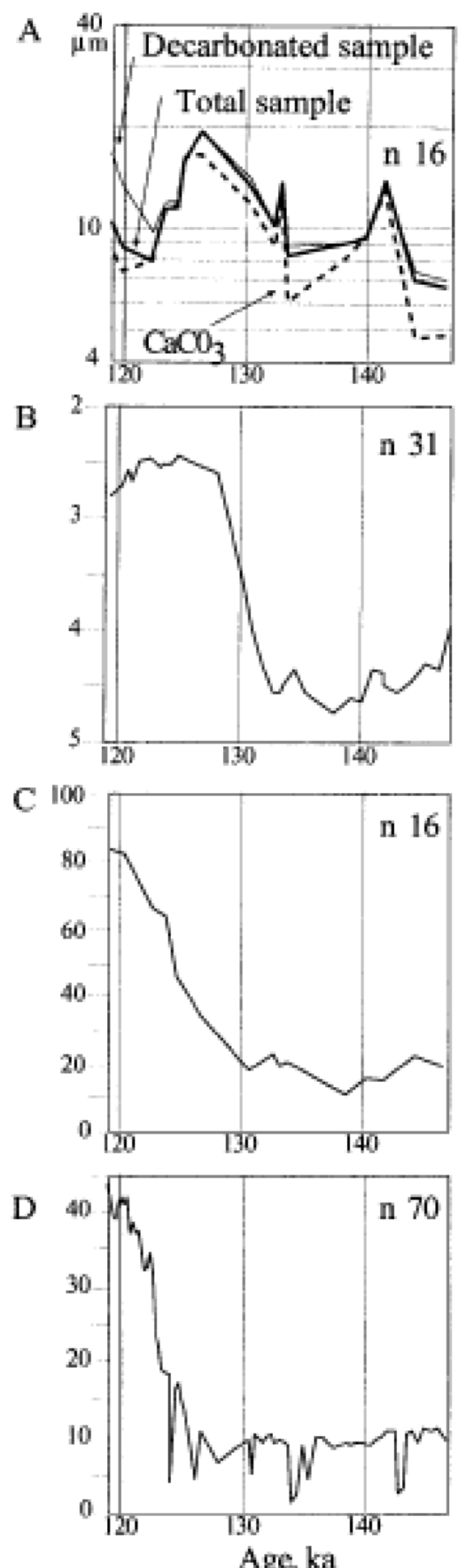

350 Fig 3. Variation of different parameters at the transition between the Pleistocene isotope stage 3516 and 5e. A) Mean grain size measured on total sediment, decarbonated sediment, and 352 calculated carbonate fraction; B) $\delta^{18} \mathrm{O}$ variation (Jerry McManus, unpublished data, in \%o); C) $353 \mathrm{CaCO}_{3}$ content; D) Reflectance measured on the red (650 $700 \mathrm{~nm}$ ) band (Ortiz et al. 1999); $n$ $354=$ number of measurements. 


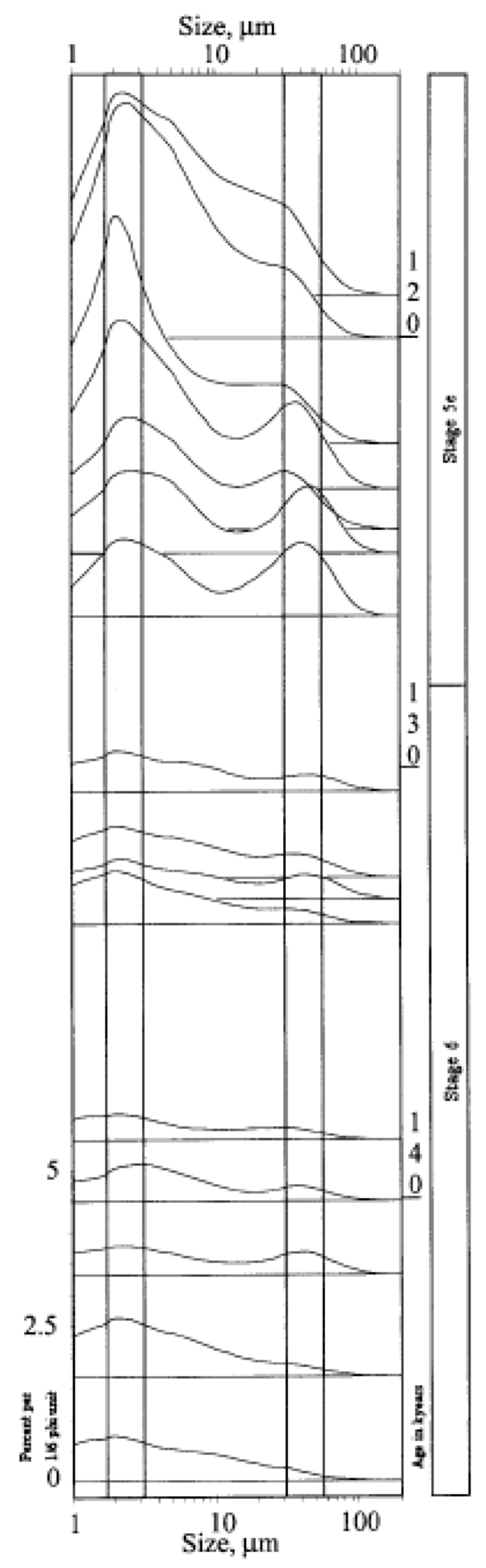

357 Fig 4. Grain size distribution of the carbonate fraction in the 16 samples from ODP Site 980.

358 The grey bars located at 2 to 3 microns and 30 to 60 microns represent the two modes, 359 nannofossils and foraminifers. 